\title{
Turning around a High Loan Defaulting Microfinance Institution: The Case of Express Savings and Loans Limited
}

\author{
Article by Siegfried Kofi Gbadago \\ Master of Science in Management by Research, Texila American University, Ghana \\ E-mail:sgbadago1@gmail.com
}

\begin{abstract}
Lenders and investors are exposed to default risk in virtually all forms of credit transactions. For the micro-finance industry in Ghana, this risk is the most critical to the sustainability of their operations. Microfinance Institutions (MFIs) can mitigate the impact of default risk on their businesses by engaging in Default Risk Management practices that are effective and reliable for their operations. In view of this concern, this study set out to examine the effects of loan default on the sustainability of a microfinance institution in Ghana by using Express Savings and Loans Company (ESLC) as a Case Study. By using trend analysis on financial records of ESLC this study established the effects of the relationships between default loans of the company and interest income, operating profit and operating margins of ESLC. The study revealed that the relationship between default loan and all variables used over the period 2009-2013 were erratic in nature. This poses critical sustainability issues for the company. To understand the trends in the incidence of default in the company few qualitative interviews were conducted with some managers of the company. It was established that the lack of monitoring of loan and high turnovers of loan officers were the main factors that significantly influence the incidence of default loan at ESLC. In reality, MFIs derive most of their interest incomes from loans, yet, not all loans granted to their clients perform well and earn the expected returns. This tends to have adverse effect on the quality of the loan portfolio. The study recommends that to minimize these effects the following measure must be in place at ESLC: effective monitoring of loans, credit training programs, and seeking the services of credit reference bureaus and private debt collectors.
\end{abstract}

\section{Introduction}

\section{Background of the study}

The provision of financial services to low income clients has been a profitable venture for most commercial Micro Finance Institutions (MFIs) in Ghana. Despite this, the micro-finance sub-sector has been plagued with a number of challenges. Among the challenges are inappropriate institutional arrangements, poor regulatory environment, inadequate capacities, lack of coordination and collaboration, poor institutional linkages, no specific set of criteria developed to categorize beneficiaries, lack of linkages between formal and informal financial institutions, inadequate skills and professionalism, and inadequate capital. Beyond these is the challenge of loan default risk management within most firms. Considering that microcredit facility (Loan) is a major activity of the MFIs and the loan portfolio constitute a significant proportion of the assets of the MFIs, the number of commercial MFIs are challenged in terms of managing default loans. In view of this the study was conducted to establish the impact of loan defaults on the sustainability of Microfinance institutions using Express Savings and Loans Limited (ESLC) as a case study.

ESLC is a commercial Microfinance institution that was incorporated in February 2007 under the company's code 1963, Act 179 by the registrar general department. As a Savings and Loans firm, loans constitute large proportion in the overall operating assets of the company. Healthy loan portfolios are therefore vital for smooth operations with positive influence on lending capacity, earnings and profitability. 
Thus, default loan is a major problem that threatens the sustainability of any MFI. Loan defaults has its antecedents: the historical development of development donors and nongovernmental organizations (NGOs) that helped in the past to poverty left impressions on the minds of many clients that loans are not to be paid back. The incidence of loan default in the Ghanaian micro-finance sub-sector has been on the rise in recent years as their loan portfolio increases despite efforts by these financial institutions to deal with it. The rapid expansion of the loan books without proper due diligence may be largely attributable to this sharp rise in the GHAMFIN annual report (2008), the total default loans of the MFI stood at 6\% in 2004 and by 2006, it has shot up to $9 \%$. With loans and Advances making over $50 \%$ of the total operating assets of MFIs, if the trend of the incidence of default loans continues, it will have a huge negative impact on the operations of the MFIs in Ghana. This issue has gained increased attention in recent years because of its adverse effects on the banking and non-banking financial institutions and the country's economy as a whole. The immediate consequences of default loans are the reduction in profitability through disposal costs like provisions for credit losses and direct write-offs for bad debts and shrinking of loan able funds. Large amounts of default loans in the banking and non-banking financial system have at many times threatened the failure and actually collapsed many banks and microfinance institutions.

\section{Problem statement}

Loan portfolio makes up the largest operating assets and source of revenue of most financial institutions. However, the loans given out do not perform well as a result of defaults which adversely affect the profitability and overall financial performance of the financial institutions.

Many financial institutions in Ghana are confronted with the challenge of rising defaults in loan portfolios despite strategies been used to reduce it. Express savings and loan is one of the Micro finance institutions with a bad trend in the health of their loan portfolio in recent years. Parnell Kerr Forster (PKF)' annual reports show that default loan ratio went up from $2.7 \%$ in 2009 to $15.7 \%$ in 2010 and by $7.4 \%$ in the year 2013. Over the past years, the Company has gone through a lot of challenges that have resulted in net losses been declared. Some of these challenges are the high cost funding of the loan portfolio through expensive deposits in the absence of fresh equity, high staff turnover resulting in loan delinquencies and loss of interest income and high operational costs. In sum, the problem of loan default calls for an effective management strategy to cause a change before it gets out of hand and this research work seeks among other objectives to come up with recommendations that will help arrest this deteriorating trend or least help reduce the rate of loan default in MFIs.

\section{Objectives of the study}

The general objective of the study is to examine the effects of loan default on the sustainability of a microfinance institution in Ghana. A sustainable MFI is able to make contributions from its lending activities towards financing the fixed costs. In other words, it is able to make profit at a certain stage of its operations and continue to make profit after that.

Specifically, the study aimed at:

- Assessing the trends in default loans of Express Savings and Loans

- Assessing the impact of default loans on Interest income of Express savings and Loans

- Assessing the impact of default loans on operating profit of Express savings and Loans

- Assessing the trends in Operational Sufficiency of Express savings and Loans

- Identify the critical factors accounting for the incidence of default loans of Express savings and Loans

\section{Research questions}

The research work seeks to find answers to the following questions: 
- What are the trends of default loan at Express Savings and Loans Limited?

- What effect does the incidence of default loans have on interest income at Express Savings and Loans Limited?

- What effect does the incidence of default loans have on operating profit of Express Savings and Loans Limited?

- What are the trends in Operational Sustainability of Express savings and Loans Limited?

- What are the factors accounting for the incidence of default loans of Express savings and Loans Limited?

\section{Significance of the study}

In most micro-finance organizations, the primary generator of revenue is the loan portfolio. The loan portfolios play a critical role in determining the financial performance of most MFI and it can therefore be said that the healthier the loan of the MFI, the better its financial performance will be. In the light of the importance of the health of the loan portfolio, it is essential that a study be conducted to identify the problems that negatively affect the performance of the MFIs. The outcome of this project would enable Express savings and Loans Company to adopt workable strategies to control the problem of a growing default loan portfolio in the institution and thereby improve its financial performance and profitability. Secondly, the project would be of benefit to the Ghanaian banking and non-banking financial sectors as a whole since the financial (Lending institutions) in the country operate within the same environment and deal with customers of similar characteristics. Thirdly, the project could serve as a source of reference for other related research works in the future. Thus, the study would contribute immensely to the development of microfinance sector which play a significant role in the economy. This is because notwithstanding the challenges, microfinance has emerged globally as one of the effective strategies in poverty reduction with the potential for far-reaching impact in transforming the lives of the poor people.

\section{Scope of the study}

The study focuses on the default loans in the Microfinance sub-sector in Ghana with ESLC as a case study. Thus, the project seeks to establish factors that accounts for the incidence of loan default and its impacts on income interest and operating profit of ESLC. The reason for limiting the scope to ESLC is that it is one of the MFIs which have been contributing significantly to expand the frontiers of microfinance operations in Ghana since 2007. This is evidenced in table 3.5. It possesses all the unique characteristics of Microfinance institutions, engages in almost all the activities undertaken by the other MFIs in the country and also they are located in almost all of the ten regions in Ghana. Their core business is Deposit Mobilization and Granting of Loans to individuals and essentially Small and Medium Enterprises (SMEs). Additionally, microcredit activities of ESLC covers several sub- sectors of the economy which makes it a model microfinance institution and therefore a suitable MFI which could be studied and the findings reasonably generalized as what pertains in other MFIs in Ghana. The period of assessment has also been limited to 2009-2013. This is to ensure that the result reflects the current trend in the operations of ESLC.

\section{Organisation of the study}

The study is organized into five chapters. The first chapter is made up of the background of the study, the statement of the problem, the research questions, objectives of the study, the significance of the study, scope and limitation of the study and the organization of the study. Chapter two reviews literature on the Evolution of microfinance sector, definitions and causes of Default loans, performing and Default loans, Loan classification and provisioning, implication of Default loans for MFIs, Reducing the incidence of default loans and the challenges facing microfinance schemes, The institution on which this project is based is Express savings and loans company. 
Chapter three describes the Vision, Mission, Core Values and objectives of Express Savings and Loans Ltd.

Chapter Four provides the Environmental Analysis using PESTLE (Political, Economic, Social, Technological, Legal/Legislative and Environmental analysis). This is followed by Chapter Five which addresses SWOT Analysis.

Chapter Six provides identification of Central Managerial Issues that are key to the loan defaults of the company. Chapter Seven addresses recommendations that followed from the key issues identified. Chapter Eight concluded with implementation time table and key resources needed to achieve the targets.

\section{Literature review}

\section{Introduction}

This chapter reviews existing literature related to the research problem. The review of literature contextualizes the processes of loan default risk management as problems associated with the handling of default loans and it influences on business operations, profits and sustainability. Theories of risk management and loan default are examined. Secondly, key concepts' underlying the study is evaluated. To place the discussions in context, a concise profile of the micro-finance subsector is examine with a focus on the incidences of default loans within the industry.

\section{Theoretical foundations}

For purpose of this study the review of literature will focus on these two theories: Risk management and loan default theory.

\section{Risk management theory}

Since the mid-1990s risk management has undergone a dramatic expansion in its reach and significance. Risk management is transformed from an aspect of management control to becoming a benchmark of good governance for banks, hospitals, schools, charities, and many other organizations. Numerous standards for risk management practice have been produced by a variety of transnational organizations. While these many designs and blueprints are accompanied by ideals of enterprise, value production, and good governance, it is argued that the rise of risk management has also coincided with an intensification of auditing and control processes. The legalization and bureaucratization of organizational life has increased because risk management has created new demands for proof and evidence of action. In turn, these demands have generated new risks to reputation (Cornett\& Saunders, 2003). Risk management has become a vital topic for financial institutions in the 1990s. Strategically, asset/liability management systems are important tools for controlling a firm's financial risks. The management of these risks is by dynamically balancing the firm's asset and liabilities to achieve the firm's objectives over an extended time periods (Dolde, 1993).

\section{Loan default theory}

Generally, the choice of the riskiness of individual assets is an important question for bankers. It is well known that fixed-premium deposit insurance leads a bank to prefer a highvariance asset portfolio, but its effect on individual asset choice has not been carefully evaluated. Bank's examination procedures and capital adequacy standards can make the value of a bank's deposit insurance contract concave in individual asset risks. Insured bankers may therefore have a rational preference (ceteris paribus) for relatively safe individual loans, even while they prefer risky portfolio returns (Flannery, 1989).

In stark contrast to bank debt contracts, most micro-finance contracts require that repayments start nearly immediately after loan disbursement and occur weekly thereafter. Even though economic theory suggests that a more flexible repayment schedule would benefit clients and potentially improve their repayment capacity, micro-finance practitioners argue that the fiscal discipline imposed by frequent repayment is critical to preventing loan default. 
Findings suggest that, among micro-finance clients who are willing to borrow at either weekly or monthly repayment schedules, a more flexible schedule can significantly lower transaction costs without increasing client default (Field \&Pande, 2008).

\section{Understanding loan classification and provisioning}

For purposes of accounting records and loan monitoring, most financial institutions focus on activities like loan classification and provisioning for loans. These are requires by regulatory institutions to ensure that loan portfolios are healthy. On one hand, classified loans represent unpaid interest and principal outstanding, and it is normally unclear whether the bank will be able to recoup the loan proceeds from the borrower. Financial institutions usually categorize such loans as adversely classified assets on their books. This type of loan has a high rate of borrower default, and raises the cost of borrowing money for the other customers.

Loan provisioning on the other hand, is an expense set aside as an allowance for bad loans. This is also known as a "valuation allowance" or "valuation reserve". All licensed financial institutions are required to monitor and review their portfolio of credit and risk assets at least once every quarter on a regular basis. Assets are classified into four grades of risk: (i) Standard; (ii) sub-standard; (iii) doubtful; and (iv) loss. Assets in risk grades (ii) to (iv) are considered non-performing and therefore no income may be accrued on them. The Bank of Ghana has specified prudential norms for microenterprise and small business finance which take into account the characteristics of the enterprises and businesses in these two categories. Microfinance and small business loans are required to be reviewed once every month and are to be classified into (i) current, or (ii) delinquent.

Next, financial institutions also do provisioning for Portfolio at risk (PAR). This refers to loans that are late in their repayments and it is the universal measure for quality of a loan portfolio. For computation of PAR, even when only a portion of the installment is late, the entire outstanding loan balance is assumed to be at risk. This is a strict and almost punitive way of assessing an MFI's risk performance. The assumption is that a borrower that starts breaching the installment contract could easily fail to pay the entire amount. To arrive at the PAR figure, we divide the outstanding loan balances of all loans in arrears by the total outstanding loan balances. This figure is usually expressed as a percentage. The industry best practice standard for MFIs is PAR (30 days) or below 5\%. Below is a table that shows standard practices among MFIs in terms of Loans Classification and provisioning.

Table 2.1: Loans Classification and provisioning among MFIs - Bank of Ghana (NBF-2 Monthly Report)

\begin{tabular}{|l|l|l|}
\hline & Provision & Number of days of Delinquency \\
\hline 1 & $5 \%$ & Up to 30 days \\
\hline 2 & $20 \%$ & $31-60$ days \\
\hline 3 & $40 \%$ & $61-90$ days \\
\hline 4 & $60 \%$ & $91-120$ days \\
\hline 5 & $80 \%$ & $121-150$ days \\
\hline 6 & $100 \%$ & 150 days and above. \\
\hline
\end{tabular}

\section{The problem of loan default for microfinance institutions}

Default loans pose potential problems for the smooth operations of most MFIs. The interest income generated from loans contributes significantly to the profitability performance of the microfinance institutions. However, when loans become delinquent, it has a serious negative effect on the health and operations of the MF institution. One of the reasons is that, in line with the Bank of Ghana regulations, the lending institution has to make provision and charges for credit losses (bad debt/impairment) which ultimately reduce the profit level. Again, large 
default loan portfolio tends to undermine the Microfinance Company's ability to grant more credit. This is because the loanable funds tend to deplete when repayment of loans delays or fail to come. Another important implication of default loans; which is sometimes described as toxic asset is the loss of confidence on the part of depositors and investors leading to liquidity challenges. Yet again, another implication of non-performing for the microfinance institutions is the that huge amounts written off as bad debt adversely affect the growth of the shareholders wealth since the profit which is re-invested (ploughed back) into the business to grow the capital base is reduced as a result of provision for credit losses. In a similar token, dividend payment is equally negatively affected because the provision for credit losses is deducted before dividends are declared. Some foreign literatures indicate that failing banks have huge amount of default loans prior to failure and that asset quality is a significant predictor of insolvency (Berger and De Young (1997). Indeed in Ghana, most MFIs have collapsed mainly on the account of default loans. The issues discussed above show the gravity of the implication of default loans on the operations of MFIs and this study attempts to identify the major causes of these NPLs among other objectives and proffer some suggestions aimed at reducing the incidence of NPLs in MFIs in Ghana.

\section{Factors accounting for loan defaults}

Factors that account for loan default within the micro-finance subsector can be divided into three broad groups of managerial factors, client related factors and economic factors. The first and most significant is that loan assessment by the MFIs is done poorly. The saying goes; there are no bad borrowers, only bad lenders. It is argued that MFIs must strive to give the correct amount at the correct terms to economically viable businesses that are run by people of good character. Obviously if efforts on the part of the MFIs in the loan contract is not managed well default loans may occur. Berger and De Young (1997), argue that managers in most financial institutions with the problem of default loans do not practice adequate loan underwriting, monitoring and control.

Still on Managerial factors, most MFIs adopt some "carrot and stick" approach with their borrowers towards managing delinquency. The carrots being the positive motivators such as: Rebates on total interest for loans that are repaid with a perfect record, lower interest in subsequent loans, graduation to higher loan amounts, recognition certificates. The stick being the punitive measures such as: late repayment penalties, blacklisting of borrowers, more stringent loan eligibility criteria. Client education on need for a good credit history is also critical. Loan monitoring and follow-up is a critical element of an MFI. MFIs must thus invest in adequate MIS capable of giving an ageing analysis of each loan.

Follow-up of loans should be systematic. A wise man once said that it is not bright to use a hammer to kill a mosquito. Similarly MFIs must use adequate but varying pressure on borrowers, depending on the seriousness of each situation. You cannot put similar pressure on a borrower that is one day late as you would on one that is 30 days late. Using varying pressure on the borrowers is commonly referred to as the graduated terror method. The other element of systematic follow-up is escalation levels. The concept of escalation levels is twofold: The first aspect on escalation levels is on verbal contact to the delinquent borrowers, which should be first done by a relatively junior ranking officer, with the next being a higher rank in case of no response. The second aspect is on formal written communication; which should range from a polite reminder to the more severe legal demand notices. The third element of systematic follow-up is that there should be an established procedure for follow-up that must be adhered to on all delinquent loans. Documentation of the follow-up efforts and the responses is very important. Appraisal is the first defense against delinquency.

The MFIs should strive to continually train/ educate their loan officers on risk mitigation. The loan officers should also be motivated through various incentives such as performance based recognition.

If the market suddenly changes and prices of items increase due to shortage or increased demand, borrowers will have less money to pay off their loans which can lead to loan default. 
Such Market may arise due to external factors such as recession in the economy and natural calamities/disasters.

Further, the study highlights following findings and insights:

- Greater monitoring effort is associated with a higher incidence of default, suggesting that lenders scrutinize borrowers ex post - that is, after they begin to experience financial difficulties.

- Results also indicate that past performance is a poor guide to future repayment given that repeat borrowers, those with established credit histories, are more likely to default than are first time borrowers; this effect, however, is confirmed in the relevant literature.

- Married borrowers whose spouses either operate their own businesses or have independent wage income have a significantly lower risk of default.

- On the other hand, gender appears to have no significant impact on delinquency or default rates. This is an interesting finding because micro lending has tended to focus on women, with much of the early evidence indicating that default rates were not gender-neutral: the repayment rate for women generally exceeded that of male borrowers.

According to authors, overall, results confirm that much like traditional commercial lending, individual-liability lending is as important a source of financing for micro-enterprises as it is for small- or medium-sized businesses. It also fills the gap that inhibits joint-liability lenders from making larger loans that could underwrite continued business expansion.

From table 2.2, it is seen that ESLC has be experiencing shortfalls in its operations margins. Operating margins was eaten away by $27.8 \%$ in $2009,40.6 \%$ in 2010 , 31.9\% in 2011 and 35.2\% in 2012. However, ESLC had an increase on operation margins in 2013 by 22.3\%. This increase happened as a result of the company going for short term loans from other MFI at high interest rates for their operations. According to one of the study participant, they take loans with 3-6 months durations and 6-12 months location to inject capital into operations.

Table 2.2. Operational self sufficiency

\begin{tabular}{|c|c|c|c|c|c|}
\hline Item/Year & 2013 & 2012 & 2011 & 2010 & 2009 \\
\hline Operation Expense & $5,604,929$ & $5,295,490$ & $3,935,485$ & $3,230,045$ & $2,453,527$ \\
\hline Loan Loss provision & 709,971.1 & $1,867,395$ & $1,270,709$ & 904,758 & 290,956 \\
\hline Financial Cost & $5,294,708$ & $3,687,507$ & 2,408,193 & $1,638,918$ & 961,528 \\
\hline Interest Income & $14,199,422$ & $7,031,548$ & $5,184,746$ & $3,430,349$ & $2,676,098$ \\
\hline $\begin{array}{l}\text { Operational self- } \\
\text { sufficiency }\end{array}$ & $122.31 \%$ & $64.80 \%$ & $68.09 \%$ & $59.41 \%$ & $72.21 \%$ \\
\hline
\end{tabular}


Texila International Journal of Management

Volume 2, Issue 2, Dec 2016

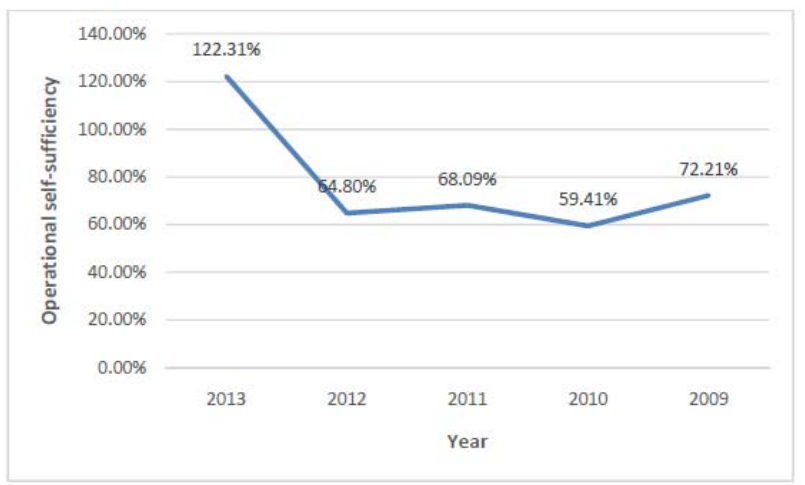

Figure 2.3 Trends in operational self-sufficiency

In looking at Table 2.2 ESLC is only covering $72.2 \%, 59.4 \%, 68.1 \%$, and $64.8 \%$ of its total costs in 2009, 2010, 2011 and 2012 respectively. It did not reach operational self-sufficiency for four years. It only reached operational self-sufficiency in 2013 with $122.3 \%$. The trends prior to 2013 indicate that eventually, the loan capital (fund capital) will be reduced by losses unless additional grants can be raised to cover operating shortfalls. This means there will be fewer funds to loan to borrowers and could result in the closing of the organization once the funds run out. The management of ESLC are in the process of making sure that this situation do not happen that is why they have taken a difficult measure of go for short terms with high interest rates to make the business sustainable.

\section{Findings from study participants}

To further understand the trend analysis in the earlier part of this section the qualitative interviews with few managers of ESLC was solicited. This was done around the following themes.

\section{The Possibility of re-capitalization}

The trends analysis revealed unsteady pattern in operations margins and profit, impairments losses and interest income. The unsteady patterns on the variables above show that the company is not financially viable and cannot be sustainable. An injection of capital into the company will be a good step toward financial stability in its operations. The study revealed that over the period 2009 to 2012 ESLC did not received any grants or capital injection. Attempt at re-capitalization has not yielded any positive result. The company therefore had to rely on client deposits. This makes the situation much riskier since, clients demand their deposits very often. When that happens payment of deposits to clients delay because the same deposits are in arrears with other loan clients.

\section{The loan write off policy}

Based the trend analysis of financial ratio of ESLC, the researcher was interested in finding out the loan write off policy of the company. An understanding of this policy helps to know whether such policy within the company had been followed. The assumption of that if such a policy was followed the company would not be experiencing the volatility within the ratio figures. It was revealed that since the establishment of the company, it had never had a policy on loan write off until December 2013 when the Board approved of a draft of such policy. According to one of the study participant, the implementation and use of the draft write off policy took effect in January 2014

\section{Dealing with the default loans in the absence of a policy}

The study reveals that ad-hoc measures were employed in dealing with default loans since the loan write off policy is not instituted between the time periods for this analysis (20092013). Some of the measures included inviting clients to the head office for re- negotiation of loan term. In the case of continues default, clients are sent to the law court for recoveries. 
Also, assets are repossessed to defray payment. According to the study participant the two processes in the latter are not often employed when dealing with default loans. Beyond these the study participants intimated there were new procedures know as Qualitative Disbursement is employed in dealing with default loan. This entails mainly the training of loan officers to be careful in granting approval for loans.

\section{Factors affecting effective loan monitoring in ESLC}

According the study participants, the factors that affect effective monitoring of loans at ESLC are largely managerial in nature. The first factor is high staff turnover. High staff turnover leads to a reduction in the quality of client analysis and other credit controls. In order to effectively follow credit assessment procedures, Loan Officers need to be trained and should shadow other loan officers. In the case of ESLC with a high turnover, such training often does not happen, and the risk of lending inappropriately increases. The second major factor is poor loan disbursement procedures. Though some security or collateral such as fixed assert like lands and building as well as movable properties like vehicle are used by borrowers to secure loan, it does not guarantee that such loan will be paid. It is not sufficient to rely solely on the judgment and experience of loan officers, though critical. The company should have a clear defined checks and parameters to ensure that it is given appropriate product to its client.

\section{Conclusion}

It is evident from the literature review that lack of proper policies in place, high staff turnover rate, and inadequate capital leading to management resorting to using short term deposits to finance loans are the major gaps in the operational sustainability of Express Savings and Loans Ltd. These gaps, if properly addressed will put the organization in a better position to serve its stakeholders.

\section{Mission, vision, core values and corporate objectives}

\section{Introduction}

Express Savings and Loans Company Limited ("ESLC” or the "Company") is a whollyowned Ghanaian private company incorporated on $27^{\text {th }}$ February 2007 to commence business on $28^{\text {th }}$ June 2007, under the Company's Code 1963, Acts 179 by the Registrar Generals Department and was duly licensed by the Bank of Ghana to operate the business of Savings and Loans in accordance with the Financial Institutions (Non-Banking Financial Institution NBFI) Law, 1993 PNDCL 328 on 14th August 2007. Its first branch at Kokomlemle in Accra was officially opened to the general public on $1^{\text {st }}$ October, 2007.

Over the past years, the Company has gone through a lot of challenges that have resulted in net losses been declared. Some of these challenges are the high cost funding of the loan portfolio through expensive deposits in the absence of fresh equity, high staff turnover resulting in loan delinquencies and loss of interest income and high operational costs.

\section{Mission}

ESLC is a financial institution committed to offering quality and affordable financial services to its valued customers in a socially responsible manner, using state of the art technology and integrity to transform their lives while making sustainable returns to its shareholders.

\section{Vision}

To become a household name in the provision of quality and affordable financial services in Ghana.

\section{Values}

The Company's core values are: 
- Teamwork: we work in partnership with our customers

- Responsiveness: we listen and communicate effectively with all our stakeholders

- Energy: we are youthful with passion

- Ability: we are professionals with the commitment to serve

- Integrity: we work with honesty and integrity in all our endeavors

- Equal opportunity: ESLC is an institution committed to equality and makes every effort to fight gender, age or class based discrimination.

\section{Objectives}

The strategic focus of ESLC is to build on the solid progress that has been achieved since it started operations in 2007. Following a complete review of the Company's business model by management, ESLC's strategic intent is to transform into a strong institution that will differentiate itself by introducing a cutting-edge operating infrastructure and management practices. Key objectives include:

- Growing the loan portfolio from the current GH\$ 20 million to GH\& 300 million by 2018. This growth will see ESLC grow its branch network from the current 17 to 22 branches countrywide, allowing the Company to reach more Ghanaians. The number of borrowers is planned to increase from the current 9,600 to an estimated 40,000 by 2018.

- Mobilizing deposits from GH\& 30 million to GH\$ 400 million by 2018. The deposit mobilization is based on the Company's low cost of funds concept as ESLC seeks to broaden its funding mix as well as lower the cost of funding. This strategy is critical for achieving operational and financial sustainability.

- Mobilizing long-term capital from a strategic partner. The key to turning around ESLC lies with raising the necessary financial resources. To this end, management's key objective for the first year of this business plan is to raise GH\$ 25 million. This be can achieved by securing the investment of a strategic partner that will provide long-term financial capital (debt and equity), as well as the necessary expertise and experience to help ESLC build the institutional capacity to develop into a wellmanaged and profitable institution.

- Implementing a Strong Risk Management System. The strategic objective is to develop the newly established risk department to identify the risks facing the Company, consistently prepare reports for submission to the managing director for action. A strong risk management system will allow the early identification of risk and the development of risk mitigation tools to be implemented at branch level.

- Achieving operational and financial sustainability. After a careful review of the previous business model, it became evident that the funding mix, which relied heavily on expensive term deposits to fund its lending operations, was flawed and could never lead to a sustainable institution.

\section{Environmental analyses}

\section{Introduction}

Environmental analysis of Express Savings and Loans Limited is carried out using PESTLE (Political, Economic, Social, Technological, Legal and Environmental) tool. In this context concentration is based on how these factors affect is abilities to manage defaults by its clients.

\section{Political}

In 2009, John Evans Atta Mills took office as President with a difference of about 40,000 votes $(0.46 \%)$ between his party, the National Democratic Congress, and the New Patriotic Party, marking the second time that power had successfully been transferred from one legitimately elected leader to another and securing Ghana's status as a stable democracy. 
President Atta Mills died in July 2012. His four years in office were marked by stability and an increase in oil production. Vice President John Dramani Mahama was sworn in shortly after Atta Mills' death. In the presidential election held in December 2012, Mahama received $50.7 \%$ of the vote, prevailing over Nana Akufo-Addo of the New Patriotic Party.

The successful inauguration of President John Mahama on 7 January 2013, following the death of incumbent John Evans Atta Mills in July 2012 and the elections in December 2012, is considered an indication of further strengthening of democracy in Ghana. International observers noted that the elections had been relatively free and fair.

Ghana's economy has been strengthened by a quarter century of relatively sound management, a competitive business environment, and sustained reductions in poverty levels. Ghana is well endowed with natural resources and agriculture accounts for roughly onequarter of GDP and employs more than half of the workforce, mainly small landholders (Source: CIA World Factbook, 2013). The services sector accounts for 50\% of GDP. Gold and cocoa production and individual remittances are major sources of foreign exchange. Oil production at Ghana's offshore Jubilee field began in mid-December, 2010, and is expected to boost economic growth. President Mahama faces challenges in managing new oil revenue while maintaining fiscal discipline and resisting debt accumulation. Estimated oil reserves have jumped to almost 700 million barrels. Ghana signed a Millennium Challenge Corporation (MCC) Compact in 2006, which aims to assist in transforming Ghana's agricultural sector. Ghana opted for debt relief under the Heavily Indebted Poor Country (HIPC) program in 2002, and is also benefiting from the Multilateral Debt Relief Initiative that took effect in 2006. In 2009 Ghana signed a three-year Poverty Reduction and Growth Facility with the IMF to improve macroeconomic stability, private sector competitiveness, human resource development, and good governance and civic responsibility. Sound macroeconomic management along with higher prices for oil, gold and, cocoa helped sustain high GDP growth in 2008-12, despite the general slowdown in the global economy during that same time period.

Although Ghana has been classified as a low middle-income country by the World Bank since 2010, its development indicators compare poorly with those of most countries in this category. Ghana has made significant progress towards attaining the Millennium Development Goals (MDGs). It is likely to attain the MDGs on the eradication of extreme poverty, universal primary education, promotion of gender equality, empowerment of women, and combating HIV/AIDS, malaria and other diseases. Ghana continues to be challenged by slow progress on reduction of under-5 mortality, improvement of maternal health and environmental sustainability.

The country is relatively stable with a formidable opposition which keeps the government on its toes to deliver on their campaign promises. The political atmosphere is conducive for the business sector which the banking and insurance sub-sector thriving well.

The general political environment does not pose any known challenge to the performance of universal banks, Non- Bank Financial Institutions (NBFIs) and Community and Rural Banks (CRBs) in relation to defaults management of their clientele.

\section{Economic}

Real GDP growth decelerated from $14.4 \%$ in 2011 to $7.1 \%$ in $2012^{1}$. The economic growth peak in 2011 was due to the start-up of oil production in the last quarter of 2010. The growth performance in 2012 was achieved despite lower cocoa and oil production.

Improved macroeconomic management and enduring political stability have not significantly transformed the structure of Ghana's economy over time. Mining and construction have sustained the industrial sector, while manufacturing has been declining as a

\footnotetext{
${ }^{1}$ IMF, 2013. According to the Bank of Ghana, real GDP growth was 7.9\% in 2012 compared to $3.2 \%$ global growth and $4.8 \%$ Sub-Saharan African growth.
} 
Texila International Journal of Management

Volume 2, Issue 2, Dec 2016

share of GDP over the past 20 years. The country needs to develop new economic sectors such as manufacturing and agro-processing in order to tackle the employment challenge and provide economic opportunities to rural areas. Table 6 below summarizes Ghana's macroeconomic indicators in the last six years. 


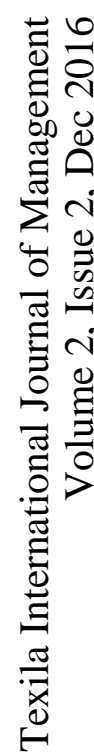

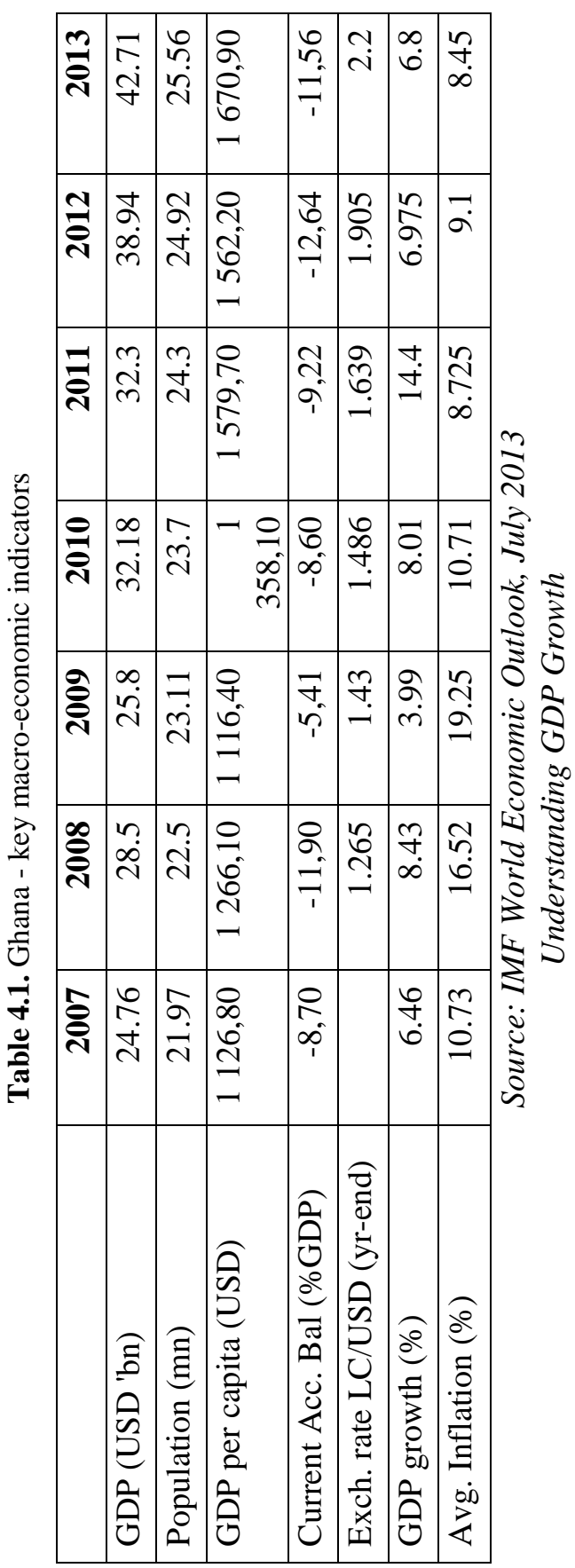


Ghana's medium-term outlook remains healthy, with projected GDP growth of 8.0\% (6.5\% non-oil) in 2013 and $8.7 \%$ (8.9\% non-oil) in 2014, well above the average annual growth rate of $6.5 \%$ for the period since 2000. Investments in the oil and gas sectors, public infrastructure and commercial agriculture are expected to drive this growth.

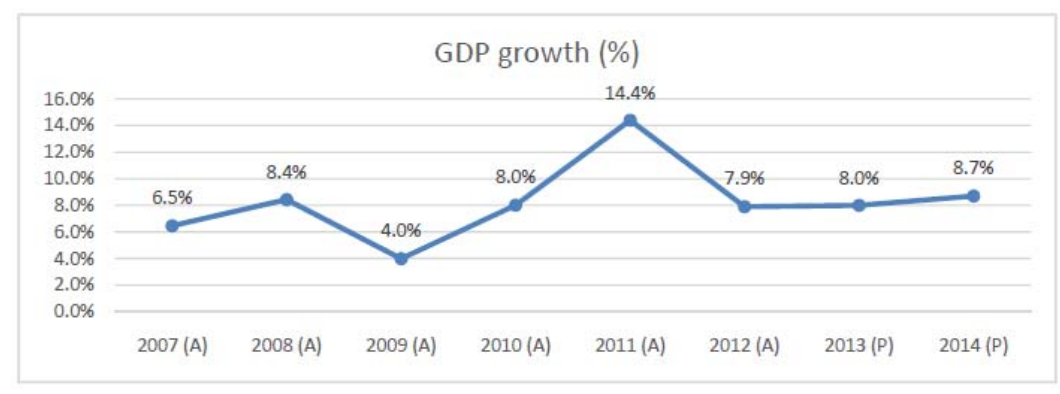

Figure 4.2: Ghana GDP growth rate

Source: Bank of Ghana Statistical Bulletin (February 2013)

The services sector remains the largest with a share of $50.0 \%$ of GDP, followed by industry (27.3\%) and agriculture (22.7\%). The growth was driven mainly by the services sector which grew by $10.2 \%$, followed by the industry sector $(7.0 \%)$, with the agriculture recording the lowest growth of $2.6 \%$ below the target rate of $4.8 \%$. The information and communications sector led the growth in the services sector recording a growth of $23.4 \%$, followed by finance and insurance which grew by $23.0 \%$. The attractive financial and insurance products offered by the banking and non-banking financial services partly accounted for the growth in this sector $^{2}$.

The influx of foreign investors as a result of the boom in the oil sector of the economy contributed to the growth in the real estate, professional, administrative and support service activities sub-sector and hotel and restaurants sub-sector which grew by $13.1 \%$ and $13.0 \%$ respectively. All other sub-sectors in the services sector recorded growth below $10 \%$. In the agriculture sector, crops sub-sector (including cocoa) recorded a $1 \%$ growth rate as a result of good staple harvests and the prolonged and favourable food season, while the Forestry subsector declined by $1.4 \%$. Fishing and livestock sub-sectors grew by $4.7 \%$ and $5.0 \%$ as a result of scaling-up of the fertilizer subsidy, agriculture mechanization and livestock and fisheries development programmes.

Construction and electricity sub-sectors recorded relatively high growth rates of $11.2 \%$ and $11.1 \%$ respectively in the industry sector, while mining and quarrying recorded $5.0 \%$ growth, Manufacturing grew by $5.0 \%$, and Water by $2.0 \%$. Though solid minerals grew significantly as well as crude oil production, drastic reduction in investment in the development of oil wells in 2012 compared to 2011, contributed to the low growth of the mining and quarrying sub-sector.

Economic growth weakened in the first half of 2013, reflecting energy disruptions and high real interest rates. As energy problems have now subsided. IMF expects full-year growth of about 7 percent in 2013, compared with 8 percent in 2012. Inflation has risen temporarily above 11 percent, as a result of the significant fuel price adjustments earlier in the year. The main risks to the economy arise from a large current account deficit—projected to increase to above 13 percent of GDP in response to much weaker gold and cocoa prices and ongoing fiscal pressures. With projected reserves of less than 3 months of imports, the economy is exposed to risks from a potentially deteriorating external environment and global financial market pressures.

The IMF further asserts that a preliminary assessment of fiscal performance during the first seven months of the year reveals significant challenges. Consistent with a slowdown in

\footnotetext{
${ }^{2}$ Source: PWC, 2013 Ghana Banking Survey: Harnessing the SME potential
} 
economic activity, revenues have fallen short of expectations, and overruns in the wage bill, electricity subsidies, and high interest payments on public debt are creating fiscal pressures. The government has responded decisively with a sharp retrenchment in other expenditure and the mid-year adoption of revenue measures, such as the reintroduction of the national stabilization and import levies. However, it will be difficult for the government to keep the deficit below 10 percent of GDP.

The IMF reports that consensus is now emerging to reduce the excessive share of wages in government spending. The biometric registration of all public sector employees, the planned introduction of new HR guidelines to control hiring, and the agreement to settle wage negotiations before the budget discussions are positive first steps. Considering the unsustainable wage dynamics of recent years, a different approach is needed, based on wage moderation and strategic choices about the size and composition of the civil service.

The government has agreed on the need to reduce subsidies and tackle the problems in the energy sector, and has reinstated the automatic fuel price adjustment mechanism. Going forward, restoration of electricity tariffs to cost-recovery levels will reduce fiscal risks and provide the needed space for higher social spending and critical infrastructure. Ghana continues to face the challenges of bringing inflation back to single digits and rebuilding a prudent reserve buffer. According to the IMF, it is important for monetary policy to remain tight until fiscal consolidation is firmly established, and possibly be tightened further if depreciation and inflation pressures heighten.

The buoyant economic performance despite scattered pitfalls led to vibrant expansion of the financial services sub-sector. Management of loan defaults by Express Savings and Loans Limited is not constrained by economic factors in Ghana but rather it is seen largely as managerial and technological challenges of the company.

This fact is supported by subsequent sections.

\section{Social}

With a total area of $230,020 \mathrm{~km}^{2}$, Ghana had an estimated population of 25.2 million inhabitants in 2012, sustained by an annual population growth rate of $2 \%$ (source: UNDP 2013 World Human Development Report). Urban areas, including two largest cities Accra and Kumasi account for an estimated $51.9 \%$ of the population.

\section{Ghana human development index}

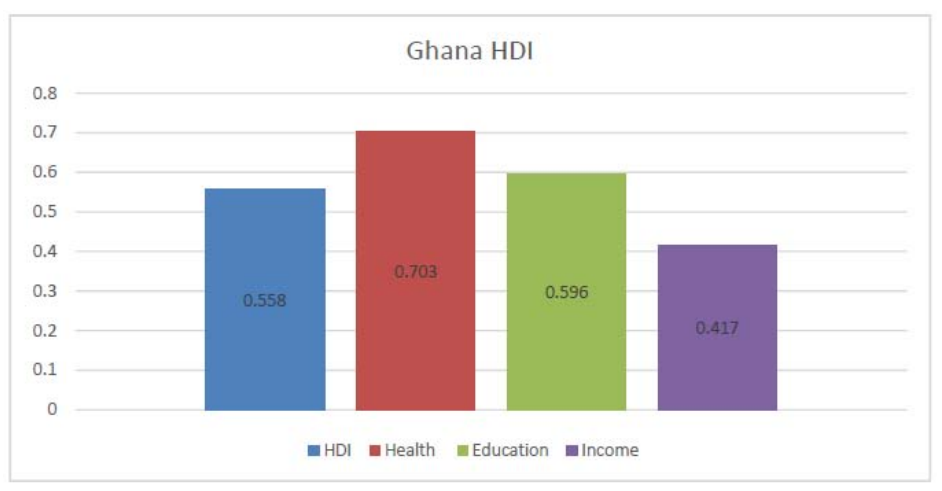

Figure 4.3. HDI: health, education and income

Source: UNDP, 2013

Each year since 1990 the Human Development Report has published the Human Development Index (HDI) which was introduced as an alternative to conventional measures of national development, such as level of income and the rate of economic growth. The HDI represents a push for a broader definition of well-being and provides a composite measure of three basic dimensions of human development: health, education and income. Between 1980 and 2012 Ghana's HDI rose by $0.9 \%$ annually from 0.391 to 0.558 today, which gives the 
country a rank of 135 out of 187 countries with comparable data. The HDI of Sub-Saharan Africa as a region increased from 0.366 in 1980 to 0.475 today, placing Ghana above the regional average.

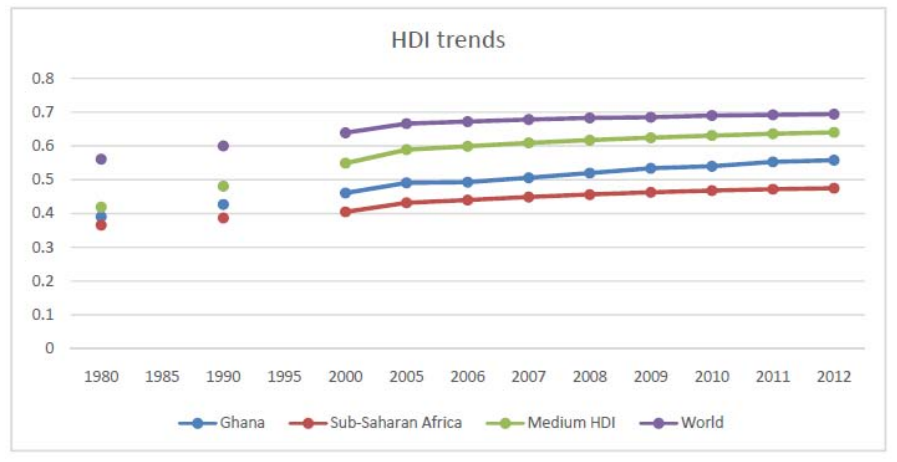

Figure 4.3. HDI Trends 1980 to present

Source: UNDP, 2013

Social development organisations like DANIDA, GTZ and USAID played a lot of funding roles in non-payable loans in the early 1980s to 1990s in Ghana. These were meant to help people come out from abject poverty and keep them economically active. Over the years, loans have been perceived by and large as a gift and this attitude permeate the whole cultural behaviour of loan clients over the country.

Subsequently, loan default rates are generally high in Ghana if stringent measures are not taken to monitor and follow clients to pay back per schedule. With weak structures and high staff turnover rates, Express Savings and Loans Limited have fallen into this social trap of clients.

\section{Technological}

The banking and the microfinance, like any other sector, is driven by technology. Accounting and banking software could make or unmake any institution in our present era since client information tracking as to deposits, loans, arrears, repayments, default rates by clients, by branch, by region and the like could only be gathered properly with a cutting-edge banking software.

Compared to Opportunity Savings and Loans Ltd that used more advanced software called Temenos Globus and EB-Accion Savings and Loans that uses Flexcube both of which are advanced internationally tried and tested banking and microfinance software, the Express Savings and Loans Limited uses in-house built software called Sikambra.

The IT Manager who designed this software later resigned his position and only available on limited times to provide technical assistance. The tracking system could not provide loan loss provision; it's not able to generate arrears report with accuracy and not well integrated with accounting system. The finance and operations teams have constantly been disagreeing on how figures should be recognized in the Sikambra.

With these, Express Savings and Loans Limited is not able to gather and provide accurate and efficient analysis and reports on its defaulting clients. These lead to abysmal performance of its loans and it is struggling to recover them.

Express Savings and Loans Limited needs to replace its banking platform if it were to advance and able to stand the competition in the present ever-changing environment.

\section{Legal/Legislative environment}

The Ghanaian banking industry is relatively liquid, solvent and profitable. The number of Deposit Money Banks and Non-Bank Financial Institutions stood at 26 and 52 respectively. One rural bank was licensed in the year 2012 to bring the total number of Rural and Community Banks (RCBs) to 136. Also, one Credit Reference Bureau was issued with an 
Texila International Journal of Management

Volume 2, Issue 2, Dec 2016

operating licence in 2012, bringing the number of Credit Reference Bureaux to three. During the year 2012, 90 microfinance institutions were granted operating licences ${ }^{3}$.

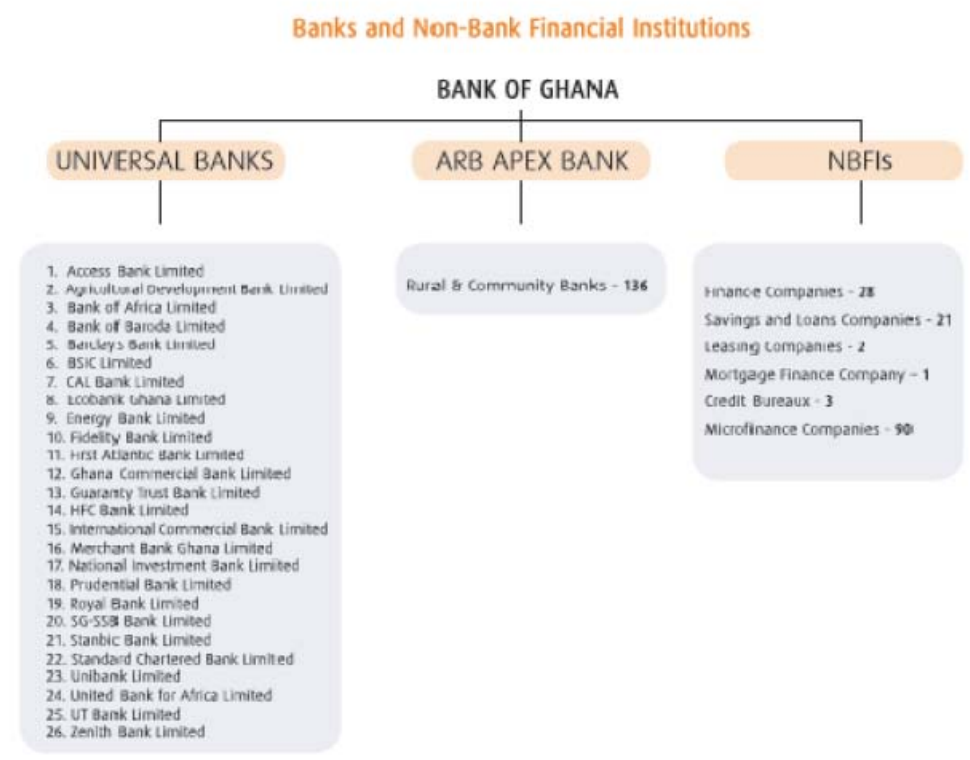

Figure 4.4. Structure of Financial Institutions

\section{Regulatory framework applicable to savings and loans (S\&L) companies}

Savings and Loans (S\&L) companies belong to a group of financial institutions previously regulated by the Financial Institutions (Non-Banking) Law, 1993 (PNDC Law 328). Following the passage of the Non-Bank Financial Institution Act, 2008 (Act 774) on $23^{\text {rd }}$ December 2008, PNDC Law 328 was repealed. A notable consequence of the advent of Act 774 is the migration of institutions previously regulated under PNDC Law 328 to other regulatory regimes. Currently, the institutions classified by the Bank of Ghana as NBFIs include:

- Finance houses

- Savings and loans companies

- Credit reference bureaus

- Leasing companies

- Mortgage finance companies, and

- Microfinance companies.

Under the third schedule to Act 774 Savings and Loans companies, amongst others, are to be regulated under the Banking Act 2004 (Act 673). However by virtue of Section 49(1) of Act 774, regulations, rules, instruments, licenses, orders and decisions made under PNDC Law 328 remain valid and binding and deemed to have been made under the Act in so far as they are not inconsistent with it. The legislation governing the period covered by this study is the PNDC Law 328.

Under the law, the Bank of Ghana is the regulatory authority for all NBFIs. To qualify for a license, S\&L companies, like other non-bank financial institutions, must have a prescribed minimum paid-up capital. This minimum capital is subject to change from time to time as the Bank of Ghana deems fit. Consequently whereas upon the promulgation of PNDC Law 328 the minimum paid-up capital was one hundred million cedis, the minimum paid-up capital is currently GHథ 7 million, recently reviewed to GHథ 15 million by the Bank of Ghana for new applications.

\footnotetext{
${ }^{3}$ Bank of Ghana Annual Report 2012
} 
The S\& L Companies were requested to get the paid up capital to GH7million by $31^{\text {st }}$ December 2012. Express Savings and Loans Ltd as of 31 ${ }^{\text {st }}$ December 2013 could not meet the capital requirement of the Bank of Ghana. It has however requested for extension of meeting the capital requirement to the end of $31^{\text {st }}$ December 2013 which the regulator granted April 2013.

There is therefore a threat to the continuity of Express Savings and Loans if the capital requirements were not met as soon as possible. The Central Bank could revoke its licence or stop it at least from mobilising deposits. Alternative could be it shall be forced to become a regulated microfinance institution thereby downgrading their current existence as a Savings and Loans Company.

\section{Environmental analysis}

In analyzing the environment of business in which Express Savings and Loans Limited operate, we look at the competition in terms of other operators carrying out deposit mobilization and granting of loans in the Savings and Loans category of the regulation.

There are a total of 22 savings and loans companies registered and operating in Ghana. The savings and loans industry is one of the fastest-growing sub-sectors in the financial sector of the Ghanaian economy. The industry has 22 companies as at May 2013, with total assets of GH\& 1.8 billion. This represents a growth rate of approximately $90 \%$ over its total assets in 2012, which stood at GH\$ 937 million. As at 31 $31^{\text {st }}$ May 2013, the 22 institutions making up the sub-sector had a combined gross loan portfolio of c. GHథ 875 million, with the four largest institutions controlling a combined $49 \%$ market share, which points to a relatively competitive market. The top two players, First Capital and $1^{\text {st }}$ National hold $15 \%$ and $14 \%$ respectively of the total loans outstanding.

Table 4.2. Market structure of loans and advances

\begin{tabular}{llcccc}
\hline Ranking & Institution & $\begin{array}{l}\text { Start year of } \\
\text { S\&L }\end{array}$ & \multicolumn{1}{l}{$\begin{array}{l}\text { Gross loans (May } \\
\text { 2013) }\end{array}$} & $\begin{array}{l}\text { Market } \\
\text { share }\end{array}$ & CAGR \\
\hline 1 & First Capital & 2009 & 133521319 & $15 \%$ & $411 \%$ \\
2 & 1ST National & 2006 & 121097934 & $14 \%$ & $122 \%$ \\
3 & Beige Capital & 2012 & 96737015 & $11 \%$ & $0 \%$ \\
4 & ProCredit & 2002 & 80814084 & $9 \%$ & $55 \%$ \\
5 & Unicredit & 2007 & 77499985 & $9 \%$ & $139 \%$ \\
6 & First Allied & 1996 & 62816371 & $7 \%$ & $30 \%$ \\
7 & Opportunity Int. & 2004 & 57891392 & $7 \%$ & $66 \%$ \\
8 & Multi-Credit & 1998 & 51877395 & $6 \%$ & $33 \%$ \\
9 & EZI & 1996 & 25969180 & $3 \%$ & $23 \%$ \\
10 & ASA & 2013 & 25684704 & $3 \%$ & $0 \%$ \\
11 & Express & 2007 & 24907633 & $3 \%$ & $90 \%$ \\
12 & EB-Accion & 2008 & 23364867 & $3 \%$ & $120 \%$ \\
13 & Midland & 1997 & 17428824 & $2 \%$ & $21 \%$ \\
14 & Advans Ghana & 2008 & 16855096 & $2 \%$ & $103 \%$ \\
15 & Women's World & 1996 & 15381460 & $2 \%$ & $19 \%$ \\
16 & Global Access & 2008 & 10829547 & $1 \%$ & $81 \%$ \\
17 & First Ghana & & 9402974 & $1 \%$ & $0 \%$ \\
18 & Adehyeman & 2005 & 8160902 & $1 \%$ & $35 \%$ \\
19 & Union & 1997 & 7890104 & $1 \%$ & $15 \%$ \\
20 & Pacific & 2004 & 4948495 & $1 \%$ & $22 \%$ \\
& & & & &
\end{tabular}


Texila International Journal of Management

Volume 2, Issue 2, Dec 2016

\begin{tabular}{llcccc}
21 & First African & 2010 & 1792613 & $0 \%$ & $34 \%$ \\
22 & Golden Pride & 2013 & 60000 & $0 \%$ & $0 \%$ \\
\hline TOTAL & & $\mathbf{8 7 4 9 3 1 8 9 4}$ & $\mathbf{1 0 0 \%}$ & \\
\hline
\end{tabular}

Source: EB-Accion, August 2013

The S\&L companies' loans and advances' Herfindahl-Hirschman Index (HHI) of 889 confirms the highly competitive nature of this market. With total loans and advances of GH\& 24.9 million outstanding, EXPRESS SAVINGS AND LOANS LIMITED is the $11^{\text {th }}$ largest savings and loans company in Ghana. However, relying on EXPRESS SAVINGS AND LOANS LIMITED's own data, the actual rank is $13^{\text {th }}$.

As at $31^{\text {st }}$ May 2013, the sub-sector had total deposits of GH\& 1.2 billion, with the four largest institutions controlling a combined 55\% market share, which points to a relatively less competitive market. The top two players, First Capital and $1^{\text {st }}$ National hold $20 \%$ and $14 \%$ respectively of the total customer deposits outstanding.

First Capital has however moved from the Savings and Loans category to a universal bank having been granted a license to operate as such by the Central Bank in $3^{\text {rd }}$ Quarter of 2013.

The S\&L companies' HHI on deposits of 1,029 confirms the market for deposits is highly competitive, albeit slightly less than the competition observed in the loans' market. With total deposits of GH4 50.1 million, EXPRESS SAVINGS AND LOANS LIMITED is the $10^{\text {th }}$ largest savings and loans company in Ghana.

With a banking penetration ${ }^{4}$ of $5 \%$ excluding microfinance and less than $10 \%$ including microfinance, there remains significant scope for growth in the Ghanaian market, providing opportunities to institutions such as EXPRESS SAVINGS AND LOANS LIMITED to grow and expand.

Express Savings and Loans Limited is therefore operating in a very competitive environment in terms of both deposit mobilization and granting of loans. Its strength and weaknesses are internal and this requires conscious efforts to make it a viable company in the next few years.

Table 4.3. Market structure of deposits

\begin{tabular}{clcrrr}
\hline Ranking & Institution & $\begin{array}{l}\text { Start year } \\
\text { of S\&L }\end{array}$ & $\begin{array}{l}\text { Deposits (May } \\
\text { 2013) }\end{array}$ & $\begin{array}{l}\text { Market } \\
\text { share }\end{array}$ & CAGR \\
\hline & & & & & \\
1 & First Capital & 2009 & 266616100 & $20 \%$ & $544 \%$ \\
2 & $1^{\text {ST }}$ National & 2006 & 178521248 & $14 \%$ & $137 \%$ \\
3 & Beige Capital & 2012 & 157276598 & $12 \%$ & $0 \%$ \\
4 & First Allied & 1996 & 124537316 & $9 \%$ & $35 \%$ \\
5 & Unicredit & 2007 & 103017487 & $8 \%$ & $153 \%$ \\
6 & ProCredit & 2002 & 88178340 & $7 \%$ & $57 \%$ \\
7 & Multi-Credit & 1998 & 71016071 & $5 \%$ & $36 \%$ \\
8 & Opportunity Int. & 2004 & 54154339 & $4 \%$ & $65 \%$ \\
9 & Midland & 1997 & 51023701 & $4 \%$ & $30 \%$ \\
10 & Express & 2007 & 50163181 & $4 \%$ & $119 \%$ \\
11 & Global Access & 2008 & 31498256 & $2 \%$ & $137 \%$ \\
12 & Women's World & 1996 & 30446762 & $2 \%$ & $24 \%$ \\
13 & EZI & 1996 & 27029557 & $2 \%$ & $23 \%$ \\
14 & EB-Accion & 2008 & 17913407 & $1 \%$ & $106 \%$ \\
15 & ASA & 2013 & 15120553 & $1 \%$ & $0 \%$ \\
16 & Union & 1997 & 12732820 & $1 \%$ & $18 \%$ \\
17 & First Ghana & & 10730600 & $1 \%$ & $0 \%$
\end{tabular}

${ }^{4}$ Calculated as a percentage of population banked versus total population 
Texila International Journal of Management

Volume 2, Issue 2, Dec 2016

\begin{tabular}{llrrrr}
18 & Adehyeman & 2005 & 9629884 & $1 \%$ & $38 \%$ \\
19 & Pacific & 2004 & 6242922 & $0 \%$ & $26 \%$ \\
20 & Advans Ghana & 2008 & 5425497 & $0 \%$ & $53 \%$ \\
21 & First African & 2010 & 4805919 & $0 \%$ & $119 \%$ \\
22 & Golden Pride & 2013 & 257802 & $0 \%$ & $0 \%$ \\
\hline TOTAL & & & $\mathbf{1 3 1 6 3 3 8 3 6 0}$ & $\mathbf{1 0 0 \%}$ & \\
\hline
\end{tabular}

Source: EB-Accion, August 2013

\section{Swot analysis}

\subsection{Introduction}

This chapter looks at the Strength, Weaknesses, Opportunities and Threats to the survival of Express Savings and Loans Limited in relation its managements of defaults; an area that threatens its sustainability as an MFI.

The analyses are summarized into the following table:- 


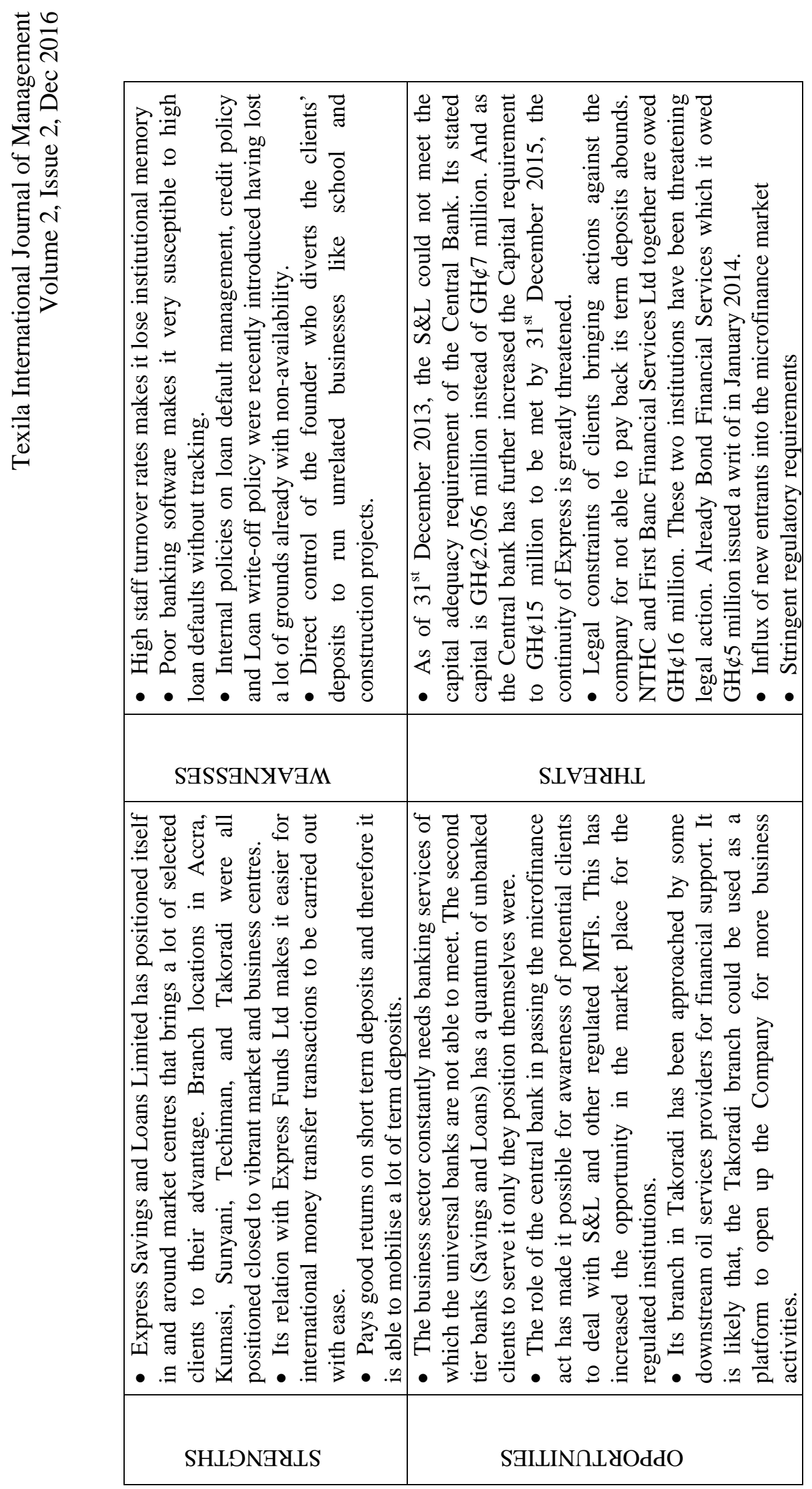




\section{Central managerial issue}

\section{Introduction}

There are two central managerial issues that we would analyze. These are:-

1) High Managerial and staff turnover

2) Poor Banking software.

\section{High managerial and operation staff turnover}

Key management like the Managing director, the Head of Finance, the Head of Operations do barely last for more than a year. As of December 2013, a new Managing Director in the person of Mr Davies SarfoYeboah took appointment in June 2013 as the $3^{\text {rd }}$ Managing director in the past 3 years. He took over from Charlotte Lily Baidoo who lasted for barely over one year after leaving to join Ideal Finance as Chief Operating Officer. By $30^{\text {th }}$ May 2014, he has been replaced.

The Head of Finance was appointed in July 2013 but resigned in February 2014. He was the $3^{\text {rd }}$ Head of Finance in the past 4 years. His predecessor lasted for 1 year and left to Vanguard Insurance as the Financial Controller.

Other operations staffs have left to join new entrants like Beige Capital and other Savings and Loans companies.

It is well known fact the shareholding structure of the company brings undue control of the company by the founder.

The structure of the company is like this:-

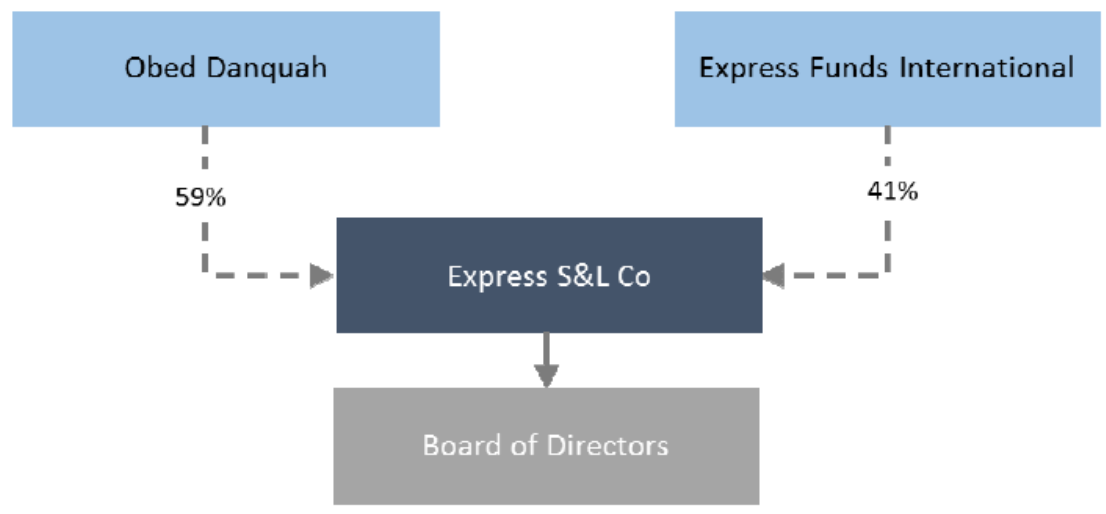

Figure 6.1 Shareholding structure of Express Savings and Loans Limited

This structure is currently being restructured through a 100\% acquisition of Express Funds International Limited by Express Savings and Loans Company Limited, with the net impact being the transfer of $41 \%$ stake currently held by Express Funds International to Mr. Obed Danquah, making him the sole shareholder.

There is immense power and influence brought to bear on key management personnel to either divert funds to unrelated projects or perform in particular activities that would bring their professional ethics to disrepute. Most key personnel resign out of frustration or are given the sack for non-compliance to those directives.

\section{The banking software}

The second aspect of the managerial issue is the banking platform being used: Sikambra. This is an in-house built by a former IT Manager Mr. Felix KobbieOffei who currently works with MASLOC.

This software is partially integrated into the accounting system. It is online software with data updated on daily basis online. It does not allow one to go back to a previous period to get any information. In other words, balances are over-written on daily basis with no possibility of data warehouse. 
There have been discussions of getting a data warehouse written and attached to Sikambra server which can enable Sikambra to perform critical analysis on loan clients balances from previous period to date, generate interest income and support the preparation of the financial report. This data warehouse talks broke down because the IT Department staffs, the System consultant from the US and Mr Offei (who still acts as IT consultant to Express Savings and Loans Limited) could not agree on a common ground for the process to take off.

An estimate was also obtained in November 2013 for the replacement of the Sikambra software in January 2014. The estimate of GH\$1.8 million could not, however, be raised immediately due to lack of free cash flow.

Thus the most critical managerial issues for Express Savings and Loans Limited are to manage retention of its key personnel and be able to change its banking software.

\section{Alternative course of action and recommendations \\ Introduction}

Alternative course of action are suggestions that should change the way things are being done and greatly improve the company for the better. This should lead to better investor inflow, retention of key experienced management and workforce, replacement of the banking platform and professional way of doing things.

\section{Structure of the shareholding}

For the Express Savings and Loans Limited to be able to make stride in the marketplace, meet the capital requirements and be able to constitute a formidable and independent board of directors, its shareholding structure needs to change.

Strategic investors must be allowed to participate in the ownership and control of the company. By this way, it will not only meet the capital requirement, failure of which threaten its existence but also fresh board and management expertise in the area of microfinance could be brought on board that could change the fortune of the company.

\section{Employment and retention of key management}

The board must be able to separate its role from that of Management. The current situation where there is Executive Chairman, an owner who is also part of key management at the same time the board chairman should be changed.

An independent board devoid of manipulating the management should be in place. Managers employed should be given targets to deliver by the Board so that the board holds the management accountable. The board and the management should not be 'managing' at the same time as the current situation suggests.

The motivation of being allowed to operate in a professional way would allow management to stay and develop long term plans for the company which it needs critically instead of the current situation where management changes on average every 7 months.

\section{Replacement of banking software}

The current banking platform needs to be replaced as a matter of urgency. There is absolutely no way that the company can develop in the market place with piecemeal operating software.

The company should explore their competitor's software and select from wide array of bespoke software that are well-tested in the Savings and Loans sub-sector. There is no need of reinventing the wheel.

Funding for the purchase of the software could come from capital injection after meeting the capital requirement with strategic investor. 


\section{Professionalism and the culture of the organisation}

Ethical behavior goes beyond avoidance of bribes and dealing in illicit drugs. Diversion of clients' deposits to fund building of international school and other construction projects that are not related to banking could be described as unethical.

Though the regulator has questioned this behavior of the board on several times, it could not be stopped due to the undue influence by the Executive Chairman.

Meeting the capital requirement is a prerequisite. This definitely requires a change in the structure in the shareholding and the board. That will diffuse the cultural change and eventual change of ethical behavior.

A strong control on the loan recovery strategies and arrears management shall thus be enforced.

\section{Implementation of recommendations}

\section{Introduction}

This study was aimed at examining the effects of loan default on the sustainability of an MFI in Ghana, using Express Savings and Loans Company as a case study. This chapter summarizes the research findings and provides implementation strategy for the recommendations.

\section{Summary of findings}

It was established from the findings of the study that between 2009 and 2013, ESLC recorded the highest default loan ratio in 2010 and this was followed by year 2013 and 2011. The lowest default loan ratio of $2.7 \%$ occurred in year 2009. In general, the trend of default loan ratios was erratic during the five-year period under consideration. The significant reduction in the default loan ratio recorded in 2009 is mainly attributed to renegotiation and refinancing of some adversely classified loans in the previous year. The default loan ratio for 2012 was also relatively low and according to one of the study participant, ESLC was using more of client deposit to keep operations going smoothly. Coupled with this, management embarked on intensive recovery program to recover most of the outstanding loan balances to improve its profitability and also engender investor confidence in the institution.

It is also seen from the moving trend analysis that default loans figures increased by 408.5\% from 2009 to 2010 . Even though the default loan figure declined by $-40.4 \%$ between 2010 and 2011, the default loan position deteriorated again between 2008 and 2009; registering an increase of $63.1 \%$ between 2011 and 2012. The analysis further reveals that even though there was constant increase in interest income from loan since 2009, these interest incomes were eroded by the significantly high provisions made for loan impairment allowances. The total provision for credit losses for the period 2009 to 2013 was 2,445,142 which represent $7.5 \%$ of the total interest income generated within the five-year period. The impact of provision for loan impairment was particularly huge in year 2010 and 2012 with ratios of $17.9 \%$ and $8.5 \%$ of their respective interest incomes. Obviously, this high provisions for bad debt had a negative impact on the overall profitability performance of ESLC. The situation is all the more worrying if one considers the fact that whilst the interest income rose from GH\$2,676,098 to GH\$3,430,349 representing 28.2\% jump from 2009 to 2010, the provision for bad debt increased from GH\$120,716 in 2009 to GH\$ 613,802 representing 408.5\% jump in the same period. It is revealed from the analysis that a considerable proportion of the operating profit was eroded by provision for loan impairment allowance. On average $144.7 \%$ of the operating profit went into provision for bad debt over the five year period. In total, an amount of $\mathrm{GH} \$ 5,043,789$ was lost from the operating profit to provision for bad debt.

The analysis further indicates that ESLC is only covering $72.2 \%, 59.4 \%, 68.1 \%$, and 64.8\% of its operating margins in 2009, 2010, 2011 and 2012 respectively. It did not reach operational self-sufficiency for four years. It only reached operational self-sufficiency in 2013 
with $122.3 \%$. This means there is less funds to loan to borrowers and the lending capacity of the company is undermined, and its investment opportunities are curtailed by the incidence of default loans.

Based on the findings from the trend analysis the study further revealed that recapitalization of the business was through client deposit and short term loans. ESLC do not have a loan write off policy and have dealt with default client in an ad-hoc manner. Again, two factors were seen to influence the rate of loan delinquency in organization. the first most important factor accounting for the incidence of default loans in ESLC high turnovers of loan officers. The second is ineffective/inadequate monitoring of loans that have been disbursed to client.

\section{Implementation strategy of recommendations}

A number of recommendations were made for Express Savings and Loans Limited to be able to get back on track and effectively become sustainable and play a key role in the marketplace.

\section{Injection of equity capital}

Equity capital is required for Express Savings and Loans Limited not only to meet the capital requirements of the Bank of Ghana but also to be able to effectively strengthen the independence and objectivity of the Board. This will take the control out of hand of one or a few persons that do not constitute a formidable board of directors to steer the affairs of the company. It is recommended that by $31^{\text {st }}$ December 2015 the company should be able to raise at least equity capital of $\mathrm{GH} \$ 13$ million. This will enable it to meet current capital requirement of the central bank which puts the cap at GH\$15 million. The company currently holds GH\$2 million equity capital.

\section{Replacement of banking software}

The existing banking software needs to be replaced as a matter of urgency. This could however happen after the injection of equity capital. It could also replace it with debt capital that is structured to effectively meet the cash flow requirements of the company. Good software in place could even attract potential investors who could inject capital to repay any debt incurred in the implementation of the banking software.

It is recommended that implementation of a new software should commence on $1^{\text {st }}$ January 2015 with a debt capital.

\section{Recruitment and retention of key management}

Three key positions are of prime importance to Express Savings and Loans Limited. These are the position of Managing Director/CEO, the Head of Finance and the Head of Operations. These positions have changed staff too quickly in the past 5 years.

Banking-cum-microfinance experienced staff of the above positions should be quickly employed. A fixed term contract of at least 3 years should be offered with delivery targets well spelt out. A fixed term contract of employment will work in the case of Express Savings and Loans due constant undue influence in the appointment and termination by the Executive Chairman of the senior management. Aggrieved employees in that type of contract could seek redress on the unexpired portion of the contract and this would also force the company to follow the good practices pertaining to the contract.

This should be implemented in conjunction with the Banking Software on $1^{\text {st }}$ January 2015.

\section{Change management \& training expert}

For the culture of the organisation to change, a Change Management \& Training Expert needs to be hired on consultancy basis or for a short duration as key member of staff. The role of this expert is to realign the management and staff with the current trend in the running of MFIs in a professional way. This expert should also be responsible for training in Organizational Behaviour (OB). 
This expert should be assisted by another expert in Credit \& Recovery Management. These appointments should be carried out and implemented by $1^{\text {st }}$ January 2015 . This will help the key senior management positions to sync appropriately with the change management and training on credit and recovery management.

\section{Conclusion}

The above changes will significantly transform the organisation and would address objectives of the research.

\section{References}

[1] Ansah, Mark Owusu (1999). Nsoatreman Rural Bank, Ghana

[2] Beaver, W. H., Kennelly, J. W., \& Voss, W. M. (1968).Predictive ability as a criterion for the evaluation of accounting data. Accounting Review, 675-683.

[3] Brealey, R., \& Myers, S. (1995). FUNDAMENTALS OF CORPO-RATE FINANCE 7/e.

[4] Bromwich, M., \& Walker, M. (1998).Residual income past and future. Management Accounting Research, 9(4), 391-419.

[5] Brydon, Lynne; Karen Legge (1996). Adjusting society: the World Bank, the IMF, and Ghana.

[6] Bushman, R. M., \& Williams, C. D. (2012).Accounting discretion, loan loss provisioning, and discipline of banks' risk-taking. Journal of Accounting and Economics, 54(1), 1-18.

[7] C. W. SMITHSON. Managing financial risk: a guide to derivative products, financial engineering, and value maximization. McGraw-Hill, New York [etc., 0-07-059354-X, 1998.

[8] Chapman, C., \& Ward, S. (1996). Project risk management: processes, techniques and insights. John Wiley.

[9] Christoffersen, P., \&Gonçalves, S. (2004). Estimation risk in financial risk management. CIRANO.

[10] Cornett, M. M., \& Saunders, A. (2003). Financial institutions management: A risk management approach. McGraw-Hill/Irwin.

[11] Cortavarria, L., Dziobek, C., Kanaya, A., \& Song, I. (2000).Loan review, provisioning, and macroeconomic linkages.

[12] Crystal, J. S., Dages, B. G., \& Goldberg, L. S. (2002). Has foreign bank entry led to sounder banks in Latin America? Current Issues in Economics and Finance, 8(1), 1-6.

[13] Cull, R., \&Murdoch, J. (2007). Financial performance and outreach: a global analysis of leading micro banks*. The Economic Journal, 117(517), F107-F133

[14] Davidson, D. E. (1997). U.S. Patent No. 5,699,527. Washington, DC: U.S. Patent and Trademark Office.

[15] Dechow, P. M., \& Ge, W. (2006). The persistence of earnings and cash flows and the role of special items: Implications for the accrual anomaly. Review of Accounting Studies, 11(2-3), 253-296.

[16] Dechow, P. M., \& Schrand, C. M. (2004). Earnings quality.

[17] Dechow, P. M., \& Skinner, D. J. (2000). Earnings management: Reconciling the views of accounting academics, practitioners, and regulators. Accounting Horizons, 14(2), 235-250.

[18] Dietrich, J. R., \& Kaplan, R. S. (1982).Empirical analysis of the commercial loan classification decision. Accounting Review, 18-38.

[19] Djurfeldt, Göran; Hans Holmén, Magnus Jirstroml (2005). The African food crisis: lessons from the Asian Green Revolution.

[20] Dolde, W. (1993).The trajectory of corporate financial risk management. Journal of Applied Corporate Finance, 6(3), 33-41.

[21] Dykstra, D. R., \& Wade, P. M. (1997). U.S. Patent No. 5,611,052. Washington, DC: U.S. Patent and Trademark Office.

[22] Dykstra, D. R., \& Wade, P. M. (1999). U.S. Patent No. 5,930,776. Washington, DC: U.S. Patent and Trademark Office.

[23] Dykstra, D. R., \& Wade, P. M. (2000). U.S. Patent No. 6,029,149. Washington, DC: U.S. Patent and Trademark Office. 
Texila International Journal of Management

Volume 2, Issue 2, Dec 2016

[24] Everett, C. R. (2010). Group membership, relationship banking and loan default risk: the case of online social lending. Relationship Banking and Loan Default Risk: The Case of Online Social Lending (March 15, 2010).

[25] Field, E., \& Pande, R. (2008). Repayment frequency and default in microfinance: Evidence from India. Journal of the European Economic Association, 6(2-3), 501-509.

[26] Field, E., \& Pande, R. (2008). Repayment frequency and default in microfinance: Evidence from India. Journal of the European Economic Association, 6(2-3), 501-509.

[27] Flannery, M. J. (1989). Capital regulation and insured banks choice of individual loan default risks. Journal of Monetary Economics, 24(2), 235-258.

[28] Foster, G. (1978). Financial Statement Analysis, 2/e. Pearson Education India.

[29] Froot, K. A., \& Stein, J. C. (1998). Risk management, capital budgeting, and capital structure policy for financial institutions: an integrated approach. Journal of Financial Economics, 47(1), 55-82.

[30] Gallardo, Joselito S. (2005). Comparative review of microfinance regulatory framework issues in Benin, Ghana, and Tanzania.

[31] Hartarska, V., \& Gonzalez-Vega, C. (2006).Evidence on the effect of credit counseling on mortgage loan default by low-income households. Journal of Housing Economics, 15(1), 63-79.

[32] Hogan, E. J. (2001). U.S. Patent No. 6,315,193. Washington, DC: U.S. Patent and Trademark Office.

[33] Huisman, R., Koedijk, K. G., \& Pownall, R. A. (1998).VaR-x: fat tails in financial risk management. Journal of Risk, 1(1), 47-61.

[34] Huq, M. M. (1989). The economy of Ghana: the first 25 years since independence.

[35] INTERNATIONAL MONETARY FUND Clarification and Elaboration of Issues Raised by the December 2004 Meeting of the Advisory Expert Group of the Inter-secretariat Working Group on National Accounts..June 2005 http://www.imf.org/external/pubs/ft/bop/2005/05-29.pdf.

[36] Johnston, M. B., Moorshead, K., Matasek, S., \& Foster, C. (2004). U.S. Patent No. 20,040,078,323. Washington, DC: U.S. Patent and Trademark Office

[37] Laeven, L., \&Majnoni, G. (2003). Loan loss provisioning and economic slowdowns: too much, too late?. Journal of financial intermediation, 12(2), 178-197.

[38] Laurin, A., \&Majnoni, G. (2003). Bank loan classification and provisioning practices in selected developed and emerging countries (No. 1). World Bank Publications.

[39] Lyon, F. (2000). Trust, networks and norms: the creation of social capital in agricultural economies in Ghana. World Development, 28(4), 663-681.

[40] Messier Jr, W. F., \& Hansen, J. V. (1988).Inducing rules for expert system development: an example using default and bankruptcy data. Management Science, 34(12), 1403-1415.

[41] Oldfield, G. S., \& Santomero, A. M. (1997).Risk management in financial institutions. In Sloan Management Review, Fall.

[42] Oni, O. A., Oladele, O. I., \& Oyewole, I. K. (2006).Analysis of Factors Influencing Loan Default among Poultry Farmers in Ogun State Nigeria. Journal of Central European Agriculture, 6(4), 619624.

[43] Page, Sheila (1993). Monetary policy in developing countries

[44] Pinto, E. J. (2006). U.S. Patent No. 7,107,241. Washington, DC: U.S. Patent and Trademark Office.

[45] Pollio G. \& Obuobie,J. (2012), Quantitative evidence on the factors that affect repayments among MFIs that use the individual-liability loan contract Micro banking Bulletin

[46] Saunders, M. N., Saunders, M., Lewis, P., \& Thornhill, A. (2011). Research methods for business students, 5/e. Pearson Education India.

[47] Siddiqui, J., \& Podder, J. (2002).Effectiveness of bank audit in Bangladesh. Managerial Auditing Journal, 17(8), 502-510.

[48] Smith, C. W., Smithson, C. W., \& Wilford, D. S. (1989).Managing financial risk. Journal of Applied Corporate Finance, 1(4), 27-48.

[49] Song, I. (2002). Collateral in Loan Classification and provisioning (No. 2002-2122).International Monetary Fund. 
Texila International Journal of Management

Volume 2, Issue 2, Dec 2016

[50] Stulz, R. M. (1996). Rethinking risk management. Journal of applied corporate finance, 9(3), 825.

[51] Stulz, R. M. (1996). Rethinking risk management. Journal of applied corporate finance, 9(3), 825.

[52] Tsamenyi, Matthew; Shazad Uddin (2008)."The Case of Rural Banks in Ghana". Corporate Governance in Less Developed and Emerging Economies.

[53] Tucker, S. (2004). U.S. Patent Application 10/905,128.

[54] Volkwein, J. F., Szelest, B. P., Cabrera, A. F., \& Napierski-Prancl, M. R. (1998). Factors associated with student loan default among different racial and ethnic groups. Journal of Higher Education, 206-237. 